\title{
Peran Auditor Internal Dalam Consulting Perusahaan
}

\author{
Subekti Catur Oktarisa \\ Email: subekti.catur.oktarisa-2019@feb.unair.ac.id \\ Universitas Airlangga
}

Wiwik Supratiwi

Email:wiwik-s@feb.unair.ac.id

Universitas Airlangga

\begin{abstract}
Abstrak
Penelitian ini membahas nilai tambah yang dapat diperoleh bisnis dari auditor internal melalui peran konsultasi mereka. Ini adalah penelitian yang memberikan gambaran tentang kegiatan konsultasi dalam konteks bisnis. Dalam kompleksitas saat ini dan masalah bisnis yang terus berubah, memanfaatkan kekayaan informasi kolektif tentang bisnis yang diperoleh oleh auditor internal untuk menambah nilai dan meningkatkan daya saing oleh sebab itu menjadi strategi yang baik. Didalam teori stewardship, audit internal akan mendukung dewan dan tim manajemen melalui peran konsultasi dan diharapkan dapat memberikan saran tentang peningkatan bisnis atau peluang investasi masa depan jika perusahaan agresif untuk usaha baru, dll. Penelitian ini merupakan kajian literature yang membahas sifat, dan tingkat aktivitas konsultasi di suatu perusahaan. Hasil penelitian menunjukkan bahwa auditor internal memberikan konsultasi atas permintaan manajemen, dewan direksi atau komite audit, secara ad-hoc untuk membantu meningkatkan operasi bisnis dan untuk mencapai tujuan organisasi. Penelitian ini berkontribusi pada literatur dengan memberikan wawasan yang lebih dalam tentang sifat dan tingkat aktivitas konsultasi yang dilakukan auditor internal.
\end{abstract}

Kata Kunci: Auditor internal, konsultasi, tata kelola perusahaan.

\section{THE ROLE OF INTERNAL AUDITORS IN COMPANY CONSULTING}

\begin{abstract}
This study examines the added value that businesses can derive from internal auditors through their consulting role. This is research that provides an overview of consulting activities in a business context. In today's complexity and constantly changing business issues, leveraging the wealth of collective business information obtained by internal auditors to add value and enhance competitiveness is therefore a good strategy. Under stewardship theory, internal audit will support the board and management team through a consulting role and are expected to provide advice on business improvements or future investment opportunities if the company is aggressive for new ventures, etc. This research is a literature review that discusses the nature and level of consulting activity in a company. The results show that internal auditors provide consultation at the request of management, the board of directors or the audit committee, on an ad-hoc basis to help improve business operations and to achieve organizational goals. This study contributes to the literature by providing deeper insight into the nature and level of consulting activity carried out by internal auditors.
\end{abstract}

Keywords: Internal auditors, consulting, corporate governance. 


\section{PENDAHULUAN}

Selama beberapa dekade terakhir, lingkungan bisnis telah mengalami perubahan yang cepat dan revolusioner dengan dampak yang luas bagi organisasi di seluruh dunia. Dalam fenomena yang berubah secara radikal ini, Audit Internal (IA) telah memperoleh peran penting dalam tata kelola organisasi. Perubahan ekonomi, meningkatnya ketergantungan pada teknologi, peluang pasar dan produk baru, peningkatan regulasi, perubahan perilaku tempat kerja, dan laju perubahan organisasi berkontribusi pada peningkatan kecepatan munculnya risiko yang dapat mengancam stabilitas bisnis. IA dianggap sebagai enabler kinerja bisnis dan penyedia pengetahuan yang dapat mendukung tujuan bisnis. Hal ini didasarkan pada argumen bahwa auditor internal memiliki pengetahuan tentang perusahaan, sehingga mereka dapat memposisikan diri sebagai konsultan ketika ada kebutuhan untuk memberikan informasi kolektif yang diperoleh selama audit untuk meningkatkan organisasi. Oleh karena itu, dalam hal ini, auditor internal dapat berpartisipasi secara proaktif seperti mendukung dewan dan tim manajemen melalui peran konsultasi dan memberikan saran yang bijaksana untuk peningkatan bisnis jika perusahaan tertarik untuk melakukan transaksi bisnis baru atau meningkatkan proses bisnis yang ada. Faktanya, auditor internal cenderung lebih memahami seluk-beluk bisnis karena pengetahuan mereka tentang bisnis dan operasinya. Dengan kata lain, bisnis dapat memperoleh nilai tambah dari peran konsultan auditor internal. Selain itu, Fungsi Audit Internal (IAF) yang efektif membantu organisasi mencapai tujuan bisnis mereka dengan menerapkan pendekatan disiplin yang sistematis untuk mengevaluasi dan meningkatkan efektivitas proses manajemen risiko, pengendalian, dan tata kelola (IPPF, 2013). Sesuai dengan Survei IA Global 2010 dari Institute of Internal Auditors (IIA), memaksimalkan IAF sangat penting untuk memenuhi tantangan baru dari lingkungan bisnis saat ini dan nilai IA akan diukur dengan kemampuannya untuk mendorong perubahan dan peningkatan positif.

Peraturan terbaru telah membuat IAF wajib berlaku untuk semua emiten yang terdaftar di Bursa Efek Indonesia, dan auditor internal harus melapor langsung ke AC (yaitu untuk meningkatkan independensi organisasi) .Versi terbaru dari Kode Tata Kelola Perusahaan menekankan pentingnya IA dengan mengamanatkan fungsi ini dan dengan demikian semua perusahaan yang terdaftar diwajibkan untuk memasukkan informasi yang berkaitan dalam laporan tahunan mereka. Di Indonesia, semua perusahaan yang terdaftar harus mendirikan IAF baik in-house atau outsourcing ke perusahaan audit terkemuka, atau dilakukan oleh pemegang saham utama, perusahaan induk, perusahaan induk, atau perusahaan pengendali dengan staf IA. Selain itu, IA dihargai jika berfungsi sebagai mitra bisnis seperti yang dirasakan oleh pelanggan 
IA seperti manajer senior dan junior di perusahaan (Yee, Sujan \& James, 2007; Yee, Sujan, James \& Leung, 2008). Sebaliknya, di negara lain seperti Inggris dan Hong Kong, IAF tidak wajib bagi perusahaan yang terdaftar di bursa masing-masing, namun, pendirian didorong untuk membantu semua anggota dewan dan manajemen ketika auditor melaksanakan tanggung jawab mereka dengan memberikan analisis, penilaian, rekomendasi, dan saran terkait aktivitas yang ditinjau (The UK Corporate Governance Code, 2010, Hong Kong's Code on Corporate Governance Practices, 2005). Peran baru IA jelas meningkatkan cakupan IA dengan memasukkan peran konsultasi (Reding et al., 2013; Selim et al, 2009). Namun, tidak banyak penelitian yang dilakukan untuk membenarkan, memperjelas dan mengakui peran baru IA dalam konsultasi (Ramamoorti, 2003; Selim et al., 2009).

Indonesia adalah negara berkembang dengan pertumbuhan ekonomi yang pesat di Asia dimana banyak perusahaan besar yang dengan sungguh-sungguh memperluas operasi bisnis mereka di dalam negeri dan global, yang secara otomatis akan meningkatkan perekonomian negara. Auditor internal memang memainkan peran mereka sebagai konsultan di bidang tersebut. manajemen risiko, manajemen perubahan, manajemen proyek, manajemen strategis, merger, dan akuisisi (M\&A) dan tata kelola (Kassim, 2011). Richards (2001) dengan jelas menyatakan bahwa penugasan konsultasi dianggap sebagai hubungan yang saling menguntungkan bagi auditor internal dan klien mereka karena mencakup beberapa langkah dari pemasaran hingga tinjauan pasca implementasi. MCCG (2012) menekankan peran dan tanggung jawab Dewan untuk memastikan bahwa perusahaan tidak hanya beroperasi dengan sukses, tetapi juga mempertahankan pertumbuhan perusahaan dalam jangka panjang. Auditor internal akan menambah nilai bisnis dengan memberikan saran kepada Dewan dan manajemen dan mengadvokasi perbaikan untuk meningkatkan struktur dan praktik tata kelola organisasi melalui peran konsultasi mereka (MCCG, 2012). Bahkan, Pemerintah Indonesia dalam berbagai kesempatan mendorong pengusaha Indonesia untuk mengambil langkah besar dalam merambah baik regional maupun internasional karena ada beberapa insentif yang diberikan bagi mereka yang melibatkan diri dalam perdagangan internasional. Sebagai mitra manajemen, IA memiliki peran sebagai penasihat untuk dimainkan dengan menambahkan nilai pada usaha terkait di luar negeri.

Nicolaesu (2013) menekankan tanggung jawab auditor internal untuk mendeteksi penipuan dalam organisasi dengan berfokus pada mendeteksi aspek menggunakan prosedur pemeriksaan merupakan cara yang paling efektif. Peran lain dalam mendeteksi penipuan dapat dilihat dari kasus WorldCom, di mana tim auditor internal berhasil menemukan bukti dengan 
memeriksa laporan keuangannya secara rahasia (Thibodeau \& Freier, 2014). Coram dkk. (2008) menemukan bahwa audit internal menambah nilai perusahaan melalui peningkatan kontrol dan pemantauan lingkungan organisasi untuk mendeteksi dan melaporkan penipuan. Perusahaan di Indonesia memiliki kesadaran yang memadai terhadap kecurangan, karena merupakan perhatian utama bisnis di Indonesia (Siregar \& Tenoyo, 2015). Berdasarkan hasil survey yang dilakukan oleh ACFE Indonesia (2016) menyatakan bahwa kasus fraud yang paling banyak terjadi di Indonesia adalah korupsi. Hal ini disebabkan banyaknya pemberitaan media mengenai pengungkapan kasus korupsi oleh Komisi Pemberantasan Korupsi (KPK). Walaupun kecurangan di Indonesia saat ini masih didominasi oleh korupsi di lembaga pemerintahan, namun bukan berarti kasus penyelewengan aset atau pelaporan penipuan tidak pernah terungkap.

Fraud merupakan penyimpangan yang dapat dilakukan oleh pihak internal maupun eksternal perusahaan. Penyebab utamanya adalah pengendalian internal yang buruk, kebijakan etika yang lemah, dan kegagalan otorisasi tugas. Auditor internal adalah salah satu alat yang direkomendasikan untuk mencegah dan mendeteksi penipuan dengan mendeteksi tempat potensial terjadinya penipuan dan menemukan bendera merah. Dengan kompetensi dan kemampuannya, auditor internal mampu untuk melaksanakan tugasnya tugas seperti yang diharapkan akan mendapatkan legitimasi dan mempertahankan pekerjaannya. Mereka bisa mendapatkan legitimasi dengan menunjukkan kompetensi mereka dilihat dari latar belakang pendidikan mereka, pekerjaan durasi, dan pelatihan lain yang mereka ikuti. Selain itu, relevansi antara yang dilakukan dan pekerjaan yang diharapkan juga bisa memberi mereka legitimasi. Penelitian tentang peran konsultasi masih dalam tahap awal (Selim dkk., 2009). Bahkan, itu akan menjadi strategi yang baik untuk auditor internal menggunakan keahlian dan pengetahuan bisnis mereka untuk memposisikan diri sebagai konsultan bisnis, untuk merespon dengan cepat terhadap perubahan dan berimprovisasi jika diperlukan untuk memenuhi permintaan pasar dalam lingkungan ekonomi saat ini. Selanjutnya, International Professional Practices Framework (IPPF) adalah pedoman otoritatif untuk auditor internal di mana perubahan baru pada definisi IA telah memperluas ruang lingkup audit internal dengan memasukkan kegiatan konsultasi. Namun, Selim et al. (2009) mengklaim bahwa sangat sedikit penelitian selanjutnya. Oleh karena itu penelitian ini bertujuan untuk menganalisis seberapa jauh auditor internal memainkan peran mereka sebagai konsultan dan bagaimana auditor internal dapat menambah nilai bisnis dengan peran konsultasi mereka. Selain itu, penelitian ini berusaha mengidentifikasi faktor-faktor yang mendorong mereka untuk melakukan peran tersebut. 


\section{TINJAUAN LITERATURE}

Dunia bisnis saat ini menghadapi transformasi fenomenal dimana banyak orang telah menjalankan bisnis mereka di banyak wilayah atau negara tanpa batasan yang ditemukan dalam berurusan dengan bisnis semacam itu di seluruh dunia (Williams, 2002). Oleh karena itu, munculnya globalisasi, peningkatan kompleksitas bisnis dan kemajuan besar teknologi informasi telah menyebabkan pergeseran paradigma dalam kegiatan yang dilakukan oleh auditor internal (fungsi nilai tambah). Selain itu, sebagai pengganti IA adalah peran "penasihat bisnis tepercaya" yang dapat membantu organisasi mencapai tidak hanya kepatuhan terhadap peraturan, tetapi juga tujuannya seputar efisiensi, pertumbuhan, dan profitabilitas (Bolger, 2011). Hal ini sesuai dengan definisi jasa konsultasi yang diberikan oleh Institute of Internal Auditors (IIA) yaitu "penasehatan dan kegiatan layanan klien terkait, sifat dan ruang lingkup yang disepakati dengan klien, dimaksudkan untuk menambah nilai dan meningkatkan kinerja organisasi, tata kelola, manajemen risiko, dan proses pengendalian tanpa auditor internal memikul tanggung jawab manajemen. Contohnya termasuk nasihat, fasilitasi, dan pelatihan" (IPPF, 2013). Ini termasuk kegiatan seperti melakukan pelatihan pengendalian internal, memberikan saran kepada manajemen tentang masalah pengendalian dalam sistem baru, menyusun kebijakan, dan berpartisipasi dalam proyek atau tim kualitas (Anderson, 2003). Oleh karena itu, telah mengangkat pentingnya IA sebagai komponen kunci menuju praktik tata kelola perusahaan yang baik (Spira \& Page, 2003).

\section{Kode Etik Auditor Internal}

Menurut Valery G. Kumaat (2011) Kode Etik Audit Internal merupakan prinsip kepribadian dan etika profesi yang harus diketahui dan mengikat setiap Auditor Internal. Kode etik audit internal merupakan pedoman bagi semua auditor internal, yang menyatakan bahwa auditor internal harus:

1. Harus jujur, objektif, dan serius dalam menjalankan profesinya.

2. Harus setia pada organisasi atau pada pihak yang dilayani.

3. Harus mampu menahan diri dari kegiatan yang bertentangan dengan kepentingan organisasi, atau kegiatan yang dapat menimbulkan prasangka yang meragukan kemampuannya untuk melaksanakan tugas dan memenuhi tanggung jawab profesionalnya. 
4. Tidak boleh menerima apapun dalam bentuk apapun dari karyawan, klien, pelanggan, pemasok, atau mitra bisnis organisasi mereka, yang secara wajar dapat diduga mempengaruhi penilaian profesional mereka.

Prinsip-prinsip tersebut antara lain meliputi integritas pribadi, independensi, kepatuhan terhadap audit charter, menjaga kerahasiaan perusahaan, kewajiban untuk mengembangkan kompetensi sesuai dengan dinamika bisnis dan sebagainya. Peran auditor internal dalam mengendalikan dan mengevaluasi risiko bisnis yang melekat dalam kegiatan operasional, keuangan, dan kepatuhan dengan peraturan yang ada (Gramling, dkk 2004). Pengendalian internal dimaksudkan untuk secara efektif dan efisien melaksanakan kebijakan operasional dan keuangannya serta peraturan perundang-undangan dapat ditaati. Fungsi auditor internal pada tingkat kapasitas dan kompleksitas tertentu dapat melekat dalam peran pengawasan direksi (Rini, 2014).

\section{Audit Internal dengan Dimensi Konsultasi Bisnis}

Departemen IA dapat memberikan nilai dengan beralih ke model yang berpusat pada pelanggan di mana auditor dapat mengadopsi beberapa cara yang serupa dengan departemen yang berorientasi eksternal sambil mempertahankan dialog dengan unit bisnis dalam organisasi, mengembangkan keterampilan yang sesuai selain memperoleh pengetahuan tentang bisnis, dan menerapkan pendekatan customer-centric yang meresap selama perikatan audit (Selim dkk., 2009). Sebagian besar tugas konsultasi berfokus langsung pada isu-isu spesifik yang berorientasi pada pelanggan (Richards, 2001). White (2007) menyatakan bahwa kesediaan auditor untuk berpartisipasi dalam negosiasi untuk memenuhi kebutuhan manajer bisnis menunjukkan adopsi pendekatan konsultasi berorientasi pelanggan dalam keterlibatan konsultasi mereka. Artinya, untuk menjadi konsultan internal yang sukses, auditor internal dan klien perlu memahami kebutuhan satu sama lain. Selama auditor internal menyadari sifat dan ruang lingkup pekerjaan keterlibatan konsultasi mereka, independensi IA secara keseluruhan tidak dapat dikompromikan (konsisten dengan definisi layanan konsultasi yang diberikan oleh IIA (IPPF, 2013). Chapman (2001) menekankan bahwa keterlibatan dalam kegiatan konsultasi telah mendorong auditor internal untuk memainkan peran yang lebih strategis dalam suatu organisasi dan selanjutnya menyarankan bahwa kegiatan konsultasi umumnya pemecahan masalah dengan auditor internal bekerja sama dengan manajemen untuk membantu dalam mencapai tujuan organisasi. Selain itu, konsultasi memerlukan pendekatan yang lebih proaktif di mana IA menjadi mitra dengan manajemen (Reding dkk., 2013). 
Menurut Pelrson (2011), organisasi umumnya lebih baik dilayani ketika auditor internal mengambil peran konseling dominan saat melakukan peran lain dan bila diperlukan. Dalam situasi yang lebih spesifik seperti mengelola proyek TI, Buckley (2011) berkomentar bahwa auditor internal harus terlibat dengan anggota tim proyek untuk membantu memberikan proyek. PricewaterhouseCoopers US (2011) melaporkan hasil survei dan memperhatikan bahwa ketika perusahaan keluar dari resesi, auditor internal memiliki kesempatan untuk meningkatkan peran mereka dengan menyelaraskan tujuan bisnis mereka dengan prioritas perusahaan baru. Selain itu, ditemukan bahwa profesional IA, dengan pemahaman yang luas tentang perusahaan mereka, dapat memainkan peran penting untuk mengadvokasi strategi pertumbuhan perusahaan, khususnya di bidang pasar negara berkembang, M\&A, media sosial, dan cloud computing dan juga untuk menavigasi labirin regulasi. Auditor internal (sebagai bagian dari peluang penciptaan nilai mereka) dapat secara agresif memainkan peran mereka dalam konsultasi untuk membantu dewan dan manajemen terutama dalam memperluas bisnis, berpartisipasi dalam kegiatan M\&A, dan mengembangkan produk baru (PricewaterhouseCoopers US, 2011). Hal ini didukung dengan baik oleh Sarens dan De Beelde (2006) di mana chief executive officer (CEO) mengharapkan IAD untuk memainkan peran nilai tambah dalam pekerjaan due diligence, mengingat pentingnya akuisisi untuk pertumbuhan organisasi. Hasil mereka menunjukkan bahwa IA selalu memiliki anggota di setiap tim akuisisi yang terdiri dari ad-hoc dan menegaskan bahwa auditor internal telah menghabiskan rata-rata 15 persen dari waktu kerja tahunan mereka untuk pekerjaan uji tuntas (Sarens \& De Beelde, 2006). Sarens dan De Beelde berkomentar bahwa CEO mana pun akan mengharapkan pentingnya peran penasihat IA di masa depan untuk meningkat di bidang manajemen proyek strategis sementara kepala auditor internal memiliki niat yang jelas untuk memainkan peran konsultatif yang lebih proaktif dalam membuat manajemen lebih reseptif dalam mengantisipasi potensi masalah.

Belajar dari kegagalan lain, misalnya World Com di AS, Barings di Inggris, dan kasus Malaysia (misalnya Perwaja dan Transmile Berhad), auditor internal tampaknya memainkan peran penting dalam bermitra dengan manajemen untuk mengatasi masalah tersebut karena sifat pekerjaan mereka sebagian besar berinteraksi dengan orang-orang dari berbagai departemen dan mereka sangat dilengkapi dengan pengetahuan bisnis yang luas dan khusus. Chia (2004) melaporkan bahwa, karena tata kelola perusahaan semakin menonjol di dunia perusahaan saat ini, komite audit di Malaysia lebih sering bertemu, dan dia sangat mendorong auditor internal untuk memiliki hubungan kerja yang baik dengan 
manajemen tanpa mengorbankan independensi dan objektivitas mereka. Selain itu, Selim et al. (2009) menemukan bahwa kemampuan untuk mandiri dan objektif ketika berkonsultasi menunjukkan peningkatan yang signifikan dari kegiatan konsultasi yang dilakukan di perusahaan Italia dibandingkan dengan perusahaan Inggris/Irlandia. Stewardship theory telah banyak digunakan dalam literatur akuntansi selama lebih dari satu dekade (Rosenfield, 1974). Tujuan laporan keuangan adalah untuk melaporkan pengendalian dan penggunaan sumber daya oleh mereka yang bertanggung jawab atas pengendalian dan penggunaan mereka kepada mereka yang bertanggung jawab (Rosenfield, 1974). Konsep stewardship diperluas karena hubungan sosial menjadi lebih kompleks (Chen, 1975).

\section{Stewardship Theory}

Stewardship Theory yang berasal dari psikologi dan sosiologi, dirancang untuk menyelidiki hubungan antara eksekutif yang bertindak sebagai steward dan termotivasi untuk bekerja demi kepentingan prinsipal (Donaldson \& Davis, 1991; Wasserman, 2006). ). Baru-baru ini teori tersebut semakin banyak digunakan dalam literatur audit internal. Misalnya, Selim et al. (2009) berpendapat bahwa stewardship theory diasumsikan lebih relevan daripada teori keagenan dalam studi mereka yang berkaitan dengan audit internal dan praktik konsultasinya di Inggris/Irlandia dan Italia. Davis, Schoorman dan Donaldson (1997) dengan tegas menyatakan bahwa teori stewardship memberikan model manusia yang lebih humanistik yang didasarkan pada model aktualisasi diri yang diperkenalkan dalam teori manajemen oleh Mc Gregor's Theory 'X' dan Theory ' $Y$ '. Teori stewardship menggunakan Teori 'Y' (dipelopori oleh McGregor (1972) untuk menggambarkan karakter manusia dimana manajemen tidak diharapkan untuk mengkhianati prinsipal dan diasumsikan berpusat pada organisasi; berusaha untuk meningkatkan kinerja organisasi dengan memuaskan prinsip-prinsip yang memungkinkan individu untuk "mematikan" kepentingannya sendiri. Sebagai contoh, Dittenhofer, Ramamoorti, Ziegenfuss dan Evans (2010) telah mengemukakan empat jenis gaya manajemen yang biasanya dikenal di mana salah satunya adalah Teori ' $\mathrm{Y}$ ' (mendukung) daripada Teori 'X' (otokratis) dan telah mengomentari teori ' $\mathrm{Y}$ ' sebagai "biasanya pengambilan keputusan yang terdesentralisasi dan operasi manajemen partisipatif, dapat mendorong partisipasi klien dalam beberapa kasus. Singkatnya, ini menunjukkan bahwa ada keselarasan tujuan antara agen dan prinsipal ketika gaya manajemen Teori 'Y' diterapkan. Oleh karena itu, berkaitan dengan peran auditor dalam konsultansi lebih bergantung pada teori stewardship (Teori 'Y') (Selim et al., 2009; Kassim, 2011) daripada keagenan (penerapan Teori ' $X$ '). Ini menjelaskan bahwa motivasi diciptakan 
dalam IAF untuk menambah nilai bisnis dalam hal membantu dewan dan manajemen untuk mencapai tujuan organisasi sebagai pengganti memainkan peran 'rule-keeper' tradisional mereka sendiri untuk mengurangi biaya agensi. Selanjutnya, peran konsultan auditor internal bersifat sukarela (bukan wajib) bagi mereka untuk menciptakan nilai tambah bagi manfaat organisasi tempat mereka terikat. Selim $d k k$. (2009) menjelaskan bahwa, keterlibatan audit internal dalam penugasan konsultasi memberikan manfaat positif untuk menambah nilai bagi organisasi dan perusahaan responden di Italia sebagian besar terkonsentrasi pada bisnis milik keluarga membuat teori kepengurusan lebih relevan karena struktur tertentu. Kepemilikan saham dan adanya keselarasan tujuan antara manajemen dan dewan (mewakili pemegang saham) tanpa banyak penurunan independensi. Kepentingan kedua belah pihak dapat diselaraskan terutama ketika manajer memiliki porsi ekuitas yang signifikan dalam organisasi di mana mereka cenderung tidak mengeluarkan informasi yang menyesatkan kepada pemegang saham dan oleh karena itu auditor cenderung melakukan pengujian tambahan, yang berarti bahwa lebih sedikit pemantauan yang diperlukan (O'Sullivan, 2000).

Dari berbagai cara IA untuk menambah nilai, keterlibatan konsultasi dirancang (yaitu melampaui pekerjaan jaminan tradisionalnya) untuk membantu meningkatkan operasi bisnis dalam hal mitigasi risiko dan peningkatan kontrol. Dengan demikian, stewardship theory digunakan dalam konteks konsultasi IA yang menjelaskan penciptaan motivasi dalam IAF untuk membantu dewan dan manajemen senior dalam mencapai tujuan organisasi. Namun, fungsi auditor internal sebagai mitra nilai tambah dapat menciptakan tindakan penyeimbangan yang sangat menantang, dan tidak banyak dari mereka yang dilengkapi dengan baik untuk menangani peran ganda ini (Chia, 2004). Oleh karena itu, auditor internal menghadapi tantangan ketika mereka perlu menyeimbangkan peluang penciptaan nilai mereka (peran konsultasi - kebutuhan untuk menjaga hubungan baik dengan eksekutif Csuite) dan pelestarian nilai (assurance role) di mana mereka perlu memberikan penilaian independen pada aktivitas operasi (Ramamoorti, 2011). Sebagian, hal itu dapat membahayakan objektivitas auditor internal dan mengancam independensi mereka sehubungan dengan peran asurans mereka (Christopher et al., 2009). Sesuai dengan Standar Atribut 1100, "Independensi dan Objektivitas", kegiatan audit internal harus independen (bebas dari pengaruh manajemen), dan auditor internal harus objektif (yaitu sikap mental yang tidak memihak) dalam melakukan pekerjaannya (IPPF, 2013). Namun, penelitian sebelumnya menunjukkan hasil yang beragam. Bou-Raad (2000) mengklaim bahwa manfaat yang diperoleh dari peran nilai tambah baru ini dapat menciptakan masalah antara perilaku 
proaktif dan kemandirian organisasi (yaitu independensi IA). Sarens dan De Beedle (2006) juga menunjukkan bahwa ada kurangnya objektivitas yang dirasakan ketika auditor internal beroperasi terutama sebagai peran pendukung manajemen serta ketika auditor menciptakan hubungan dengan Komite Audit (AC) dalam posisi yang relatif lemah. Sebaliknya, (Cooper dkk., 2009)Ahmad dan Taylor (2009) dalam temuan mereka menjelaskan bahwa efek dari sejumlah dimensi dalam ambiguitas peran dan konflik peran pada komitmen auditor internal terhadap independensi agak rendah, menunjukkan bahwa auditor internal tidak merasakan konflik ketika melaksanakan tugas peran ganda dalam memberikan layanan konsultasi dan assurance.

\section{METODE PENELITIAN}

Tujuan utama penelitian ini adalah untuk menambah pengetahuan mengenai sifat dan tingkat aktivitas konsultasi yang dilakukan auditor internal, alasan mengapa demikian, dan persepsi mereka tentang independensi dan objektivitas ketika peran tersebut sebagai nilai tambah bagi bisnis mereka. Metode penelitian yang digunakan adalah library research. Library research merupakan suatu studi yang digunakan dalam mengumpulkan informasi dan data dengan bantuan berbagai macam material yang ada diperpustakaan seperti dokumen, buku, majalah, kisah-kisah sejarah, dsb (Mardalis, 1999). Penelitian ini dilakukan untuk memecahkan suatu masalah yang berpijak pada pengkajian kritis dan mendalam terhadap bahan-bahan pustaka yang relevan. Bahan-bahan pustaka ini diposisikan sebagai sumber ide atau inspirasi yang dapat membangkitkan gagasan atau pemikiran lain.

\section{HASIL DAN PEMBAHASAN}

\section{Kegiatan Konsultasi yang Dilakukan Auditor Internal}

Salah satu Chief Audit Executives (CAE) merasa bahwa melakukan pekerjaan konsultasi adalah bagian dari definisi IA sesuai dengan IPPF (2013), namun harus dilakukan secara independen dalam hal memberikan saran untuk meningkatkan proses manajemen risiko, pengendalian dan pemerintahan Meskipun demikian, mereka akan mencari ahli outsourcing untuk melakukan tugas konsultasi jika mereka tidak memiliki keahlian di bidang konsultasi peningkatan sistem pengendalian internal. Kegiatan konsultasi biasanya berasal dari manajemen tingkat operasional yang meminta nasihat mereka dalam hal pengendalian. CAE diminta untuk memberikan nasehat sebagai konsultan internal pada tahun tersebut karena pada tahun sebelumnya ada kejadian dimana perusahaan telah melakukan kerjasama dengan 
konsultan eksternal, nasehat yang diberikan serupa dengan rekomendasi IA. Karena keadaan, mereka dipanggil sejak saat itu. Selain itu, mereka mengakui bahwa mencari keahlian eksternal berkaitan dengan mempekerjakan penyedia luar untuk melaksanakan perikatan konsultasi, atau untuk melakukan perikatan asurans dalam aktivitas di mana keterlibatan fungsi audit sebelumnya dalam pekerjaan konsultasi telah ditentukan (IPPF, 2013). Staf IA yang ada akan digabungkan dengan ahli lain (yaitu penyedia luar atau orang kedua dari departemen lain dalam organisasi yang sama) untuk melakukan pekerjaan konsultasi khusus di bidang tertentu ketika tidak ada keahlian yang cukup di antara staf IA. Memaksimalkan IAF sangat penting karena mereka memiliki kompetensi inti termasuk teknis (misalnya teknik audit) dan keterampilan untuk membantu meningkatkan operasi bisnis karena kompleksitas bisnis saat ini (IIARF, 2011b).

Hasil penelitian juga menunjukkan adanya rotasi di antara staf IA di departemen saat melaksanakan tugas IA dan staf IA akan ke area audit yang berbeda, fungsi multi-tugas, dan peluang untuk tugas konsultasi berdasarkan keahlian mereka. Oleh arena itu harus ada auditor lain untuk melakukan review independen terhadap efektivitas sistem pengendalian teknologi informasi dan untuk memberikan pendapat atas kerangka pengendalian teknologi informasi pada audit berikutnya. CAE juga berbagi pengalaman mereka di mana staf IA menerima paparan baru dengan merotasi mereka pada penugasan karena semua anak perusahaan melakukan jenis bisnis yang berbeda. Selain itu, semua responden merasa bahwa pemisahan unit konsultan dari unit yang melakukan audit (assurance) bukanlah suatu keharusan; dengan kata lain tidak perlu memisahkan unit-unit IA untuk kegiatan konsultasi.

\section{Alasan untuk Melakukan Peran Auditor Internal}

Hasil penelitian menemukan bahwa melakukan pekerjaan konsultasi adalah bagian dari definisi IA (IPPF, 2013), namun harus dilakukan secara independen dalam hal memberikan saran untuk meningkatkan proses manajemen risiko, pengendalian dan pemerintahan. Misalnya, salah satu CAE merasa bahwa melakukan pekerjaan konsultasi adalah bagian dari tugas mereka karena mereka mengklaim bahwa mereka memahami manajemen risiko dengan baik. Perikatan konsultasi diminta untuk meningkatkan kinerja operasi yang ada atau yang baru (dalam hal risiko dan pengendalian) dan untuk membantu perusahaan mencapai tujuan. Bahkan tidak ada pihak lain yang terlibat dalam meminta nasihat konsultasi mereka kecuali AC, manajemen auditee dan manajemen senior. Bank Sentral dan masyarakat umum akan meminta saran konsultasi mereka bukan untuk masalah tertentu. Misalnya, mereka meminta saran untuk pengembangan produk baru sebelum peluncuran dan yang lainnya tentang pengurangan waktu 
yang dibutuhkan untuk menyetujui pinjaman.

Dalam hal konsultasi manajemen risiko, hasil penelitian menunjukkan bahwa beberapa tugas telah dilakukan seperti memfasilitasi proses penilaian risiko tahunan, memfasilitasi penilaian pengendalian manajemen (kontrol latihan penilaian diri dengan menyelenggarakan lokakarya) dan saran desain kontrol. Selanjutnya, orang dengan pengalaman yang luas (lebih dari dua puluh tahun) dalam audit jaminan (di berbagai industri) dan konsultasi (misalnya implementasi program manajemen risiko dan CG), secara signifikan memandang bahwa IA harus memberikan layanan konsultasi bila diperlukan. Kemudian orang yang memiliki pengalaman memberikan tugas konsultasi uji tuntas seperti memfasilitasi diskusi manajemen mengenai kriteria evaluasi kandidat akuisisi potensial dan memberikan umpan balik tentang sektor potensial atau operasi tertentu. Mereka mengklaim bahwa mereka memiliki kemampuan untuk melakukannya sehingga manajemen telah meminta bantuan untuk menjaga hubungan baik dengan manajemen dalam menunjukkan nilai tambah mereka untuk organisasi dalam hal konsultasi sambil mempertahankan independensi mereka dengan melaporkan secara fungsional ke AC dan memberikan pekerjaan jaminan.

\section{Peran Auditor Internal dalam Menjalankan Fungsi Independensi dan Objektivitas}

Mengenai independensi dan objektivitas IA, sebagian besar menganggap tidak ada masalah penurunan nilai yang muncul saat melakukan aktivitas konsultasi. Ini karena sebagai auditor internal mereka menyadari ruang lingkup pekerjaan mereka, pengungkapan waktu yang tepat waktu yang dihabiskan untuk pekerjaan konsultasi, batasan kerja, IPPF Standar, dan akhirnya peran komitmen mereka sebagai konsultan. Selanjutnya, CAE ditemukan tidak hanya melapor langsung ke AC (tingkat grup dan/atau tingkat perusahaan) secara fungsional, tetapi juga kepada manajemen senior/top (yaitu atasan langsung mereka) pada tingkat administratif.

Untuk melakukan kegiatan konsultasi, CAE setuju bahwa isi Piagam IA cukup untuk menggambarkan hal-hal yang boleh dan tidak boleh dilakukan sehubungan dengan ruang lingkup pekerjaan dan tanggung jawab mereka terhadap konsultasi. Mereka juga menekankan proses penyaringan untuk proyek konsultasi dengan batasan penerimaan penugasan yang mungkin mengancam objektivitas dan rotasi auditor pada penugasan. Misalnya, ketersediaan auditor serta pengetahuan mereka tentang materi pelajaran harus dipertimbangkan terlebih dahulu sebelum menyetujui dan memperoleh persetujuan AC untuk melakukan perikatan. Berkenaan dengan kebijakan organisasi yang memberikan wewenang kepada IA untuk menunjukkan komitmen organisasi auditor internal untuk melakukan kegiatan IA, CAE mempertahankan Piagam IA sebagai tanggung jawab pekerjaan formal dengan penekanan pada 
aspek-aspek tertentu yang berkaitan dengan keterlibatan konsultasi dalam Piagam IA seperti: 1) mengidentifikasi misi dan perencanaan yang selaras dengan tujuan manajemen; 2) terbuka untuk permintaan manajemen; 3) menyediakan rencana audit yang berfokus pada area risiko bisnis yang tinggi, menunjukkan komitmen mereka terhadap pelaksanaan kegiatan konsultasi.

\section{SIMPULAN}

Sehubungan dengan independensi dan objektivitas IA, studi ini juga menemukan tidak ada masalah penurunan nilai yang muncul saat melakukan aktivitas konsultasi. Hal ini karena auditor internal menyadari ruang lingkup pekerjaan mereka, pengungkapan waktu yang tepat waktu yang dihabiskan untuk pekerjaan konsultasi, batasan kerja, IPPF Standar, dan akhirnya peran komitmen mereka sebagai konsultan. Selanjutnya, hasil dari penelitian sebelumnya, auditor ditemukan tidak hanya melapor langsung ke AC (tingkat grup dan/atau tingkat perusahaan) secara fungsional, tetapi juga kepada manajemen senior/top (yaitu atasan langsung mereka) pada tingkat administratif. Sehubungan dengan kebijakan organisasi yang memberikan wewenang kepada IA untuk menunjukkan komitmen organisasi auditor internal untuk melakukan kegiatan IA, hasil menunjukkan bahwa mempertahankan Piagam IA sebagai tanggung jawab pekerjaan formal dengan penekanan pada aspek-aspek tertentu yang berkaitan dengan keterlibatan konsultasi dalam Piagam IA seperti: 1) mengidentifikasi misi dan perencanaan yang selaras dengan tujuan manajemen, 2) terbuka untuk permintaan manajemen, dan 3) menyediakan rencana audit yang berfokus pada area risiko bisnis tinggi, menunjukkan komitmen mereka terhadap pelaksanaan kegiatan konsultasi. Gagasan ini konsisten dengan tindakan penyeimbangan peran ganda (konsultasi dan jaminan) masalah yang dijelaskan dalam penelitian sebelumnya (Chia, 2004; Ramamoorti, 2011). 


\section{DAFTAR PUSTAKA}

Association of Certified Fraud Examiners (ACFE). 2017. What is Fraud? (Online), (http://www.acfe.com/fraud-101.aspx), diakses pada 25 Oktober 2017.

Anderson, U. (2003). Assurance and consulting services. In A. D. Bailey, A. A. Gramling, \& S. Ramamoorti (Eds.), Research opportunities in internal auditing (pp.97-129). Altamonte Springs, Florida: The Institute of Internal Auditors Research Foundation.

Bolger, D. (2011). Stakeholdes' expectations and perceptions survey: A component of the CBOK study - A call to action: Stakeholders' perspectives on internal auditing. Altamonte Springs, Florida: The Institute of Internal Auditors Research Foundation (IIARF).

Bou-Raad, G. (2000). Internal auditors and a value-added approach: The new business regime. Managerial Auditing Journal, 15(4), 182-187.

Buckley, S. (2011). IT project management. Internal Auditor, 68(4), 21-23.

Chapman, C. (2001). Raising the bar. Internal Auditor, 58(2), 55-59.

Chen, R. S. (1975). Social and financial stewardship. The Accounting Review, 50(3), 533-543.

Chia, A. (2004, September 18). Internal auditors-partners in boosting corporate governance. Business Times, p.6.

Christopher, J., Sarens, G., \& Leung, P. (2009). A critical analysis of the independence of the internal audit function: Evidence from Australia. Accounting, Auditing \& Accountability Journal, 22(2), 200-220. http://dx.doi.org/10.1108/09513570910933942

Cooper, B., Leung, P., Dellaportas, S., Ahmad, Z., \& Taylor, D. (2009). Commitment to independence by internal auditors: the effects of role ambiguity and role conflict. Managerial Auditing Journal.

Coram, P., Ferguson, C. \& Moreney, R. 2008. Internal audit, alternative internal audit structures and the level of misappropriation of assets fraud. Accounting and Financing, (Online), 48: 543-559, (http://www.researchgate.net), diakses pada 3 December 2017.

Donaldson, L., \& Davis, J. H. (1991). Stewardship Theory or Agency Theory: CEO Governance and Shareholder Returns. Australian Journal of Management, 16(1), 49-64. http://dx.doi.org/10.1177/031289629101600103

Gramling, A. A., Maletta, M. J., Schneider, A., \& Church, B. K. (2004). the Role of the Internal Audit Function in Corporate Governance: a Synthesis of the Extant Internal Auditing Literature and Directions for Future Research. Journal of Accounting Literature, 23, 194. Retrieved from http://search.proquest.com/docview/216303617?accountid=26357

Hong Kong's Code on Corporate Governance Practices. (2005). Hong Kong: Stock Exchange of Hong Kong Limited. Retrieved from http://www.corpgov.deloitte.com/site/ChinaEng/hongkong-governance-profile/.

Hong Kong Institute of Certified Public Accountants. (2005). Internal control and risk management: A basic framework. Retrieved from http://app1.hkicpa.org.hk/corporate_relations/media/pressrelease/2005/ICRM_Guide_fin al.pdf. 
(IIARF) (The) Institute of Internal Auditors Research Foundation. (2011b). Global summary of the common body of knowledge study 2010, Imperatives for change (Report V). Altamonte Springs, Florida: IIA Research Foundation.

The International Professional Practices Framework. (2013). Altamonte Springs, Florida: The Institute of Internal Auditors Research Foundation. Available from https://na.theiia.org/standards-guidance/Pages/Standards-and-Guidance-IPPF.aspx.

Kassim, M. A. (2011). The role and level of compliance by internal auditors in implementing the enterprise risk management (ERM) and their influence on organizational performance: A case of Malaysian high performance GLCs (Doctoral Thesis). Universiti Teknologi MARA(UiTM), Shah Alam.

Malaysian Code of Corporate Governance (MCCG). (2012). Malaysian code on corporate governance 2012. Kuala Lumpur, Malaysia: Securities Commission Malaysia. Retrieved from http://www.sc.com.my/wp-content/uploads/eng/html/cg/cg2012.pdf.

McGregor, D. (1972). An uneasy look at performance appraisal. Harvard Business Review, 50(5), 133-138.

Nicolaescu, E. 2013. Internal Auditors' Role in Detecting Fraud. Contemporary Readings in Law and Social Justice, (Online), 5(1): 106-111, (http://go.galegroup.com), diakses pada 22 Oktober 2017.

O'Sullivan, N. (2000). The impact of board composition and ownership on audit quality: Evidence from large UK companies. The British Accounting Review, 32(4), 397-414. http://dx.doi.org/10.1006/bare.2000.0139

Pelrson, J. (2011). The broken triangle: The relationship between internal audit, management and the audit committee. Paper presented at the 2011 IIA International Conference of Internal Auditing held at the Kuala Lumpur Convention Centre, 10-13 July. Malaysia: Kuala Lumpur.

Ramamoorti, S. (2003). Internal auditing: History, evolution, and prospects. In A. D. Bailey, A. A. Gramling, \& S. Ramamoorti (Eds.), Research opportunities in internal auditing (pp.1-23). Altamonte Springs, Florida: The Institute of Internal Auditors Research Foundation.

Reding, K, F., Sobel, P. J., Anderson, U. 1., Head, M. J., Ramamoorti, S., Salamasick, M., \& Riddle, C. (2013). Internal Auditing: Assurance and Consulting Services (3 rd ed.). Altamonte Springs, Florida: The Institute of Internal Auditors Research Foundation.

Richards, D. (2001). Consulting auditing: Charting a course. Internal Auditor, 58(6), 30-35.

Rini, R. (2014). The effect of audit committee role and sharia supervisory board role on financial reporting quality at Islamic banks in Indonesia. Journal of Economics, Business, and Accountancy | Ventura, 17(1), 145. https://doi.org/10.14414/jebav.v17i1.273

Rosenfield, P. (1974). Stewardship. In J. D. Cramer \& G. H. Sorter (Eds.), Objectives of financial statements, Vol.2 - Selected papers (pp.123-140). New York: American Institute of Certified Public Accountants.

Sarens, G., \& De Beelde, I. (2006). The relationship between internal audit and senior 
management: A qualitative analysis of expectations and perceptions. International Journal of Auditing, 10(3), 219-241. http://dx.doi.org/10.1111/j.1099-1123.2006.00351.x

Selim, G., Woodward, S., \& Allegrini, M. (2009). Internal Auditing and Consulting Practice: A Comparison between UK/Ireland and Italy. International Journal of Auditing, 13(1), 925. http://dx.doi.org/10.1111/j.1099-1123.2008.00395.x

Siregar, S.V. \& Tenoyo, B. 2015. Fraud awareness survey of private sector in Indonesia. Journal of Financial Crime, (Online), 22 (3): 329-346, (http://www.emeraldinsight.com), diakses pada 14 November 2017.

Spira, L. F., \& Page, M. (2003). Risk management: The reinvention of internal control and the changing role of internal audit. Accounting, Auditing \& Accountability Journal, 16(4), 640- 661. http://dx.doi.org/10.1108/09513570310492335

The UK Corporate Governance Code. (2010). London: Financial Reporting Council. Retrieved from http://www.ecgi.org/codes/documents/uk_cgc_june_2010_en.pdf.

Thibodeau, J. \& Freier, D. 2014. Auditing and Accounting Cases: Investigating Issues of Fraud and Professional Ethics, Forth Edition. New York: McGraw Hill.

Valery, G. K. (2011). Internal audit. Jakarta: Penerbit Erlangga

Wasserman, N. (2006). Stewards, agents, and the founder discount: Executive compensation in new ventures. Academy of Management Journal, 49(5), 960-976. http://dx.doi.org/10.5465/AMJ.2006.22798177

White, S. D. (2007). The auditor as internal consultant. Internal Auditor, 64(2), 59-64.

Williams, E. J. (2002). The impact of globalization on internal auditors: The evolution of internal auditing. Altamonte Springs, Florida: The Institute of Internal Auditors Research Foundation.

Yee, C. S. L., Sujan, A., \& James, K. (2007). The perceptions of the Singaporean manager class regarding the role and effectiveness of internal audit in Singapore. Paper presented at the Fifth Asia Pacific Interdisciplinary Research in Accounting (APIRA) Conference, Auckland, New Zealand, 8-10 July (pp. 1-19). Retrieved from http://ro.uow.edu.au/cgi/viewcontent.cgi?article=1438\&context=commpapers

Yee, C. S. L., Sujan, A., James, K., \& Leung, J. K. S. (2008). The Perceptions of Singaporean internal audit customers regarding the role and effectiveness of internal audit. Asian Journal of Business and Accounting, 1(2), 147-174. 